\title{
Improving logging process efficiency in the context of rational natural resource management
}

\author{
M. Zyryanov, V. Shvetsov*, I. Milyaeva, and E. Dozhdev \\ Lesosibirsk branch of FSBEI of Higher Education 'Siberian State Technological University of \\ Science and Technology named after Academician M.F. Reshetnev', 29 Pobedy str., Lesosibirsk, \\ 662543, Russian Federation
}

\begin{abstract}
Until recently, only the trunk was recognized as valuable in the forest industry, and everything else, including the crown, was considered waste that cluttered cutting areas, and a hazardous raw material in the event of possible fires. Currently, only about 700 thousand tons of wood waste is used, which is no more than $4 \%$ of the resulting amount of potential raw materials that could be used at wood processing enterprises. Analysis of formation and use of logging waste showed that today coniferous greenery has found its application as a raw material for coniferous flour production directly at the cutting area. After the needles are separated, branches that have not found further use remain in the cutting area. One of the promising areas for logging waste use after needle separation is production of wood flour, which has found its wide application in many industries.
\end{abstract}

At present, in the timber and timber processing industry of Russia, the satisfaction of annually increasing demand for timber and products of their processing is achieved by increasing the volume of logging, but at the same time, the efficiency of using woody biomass of the forest fund remains relatively low compared to other countries. Possessing more than a quarter of the world's forest resources, the Russian Federation occupies only $3 \%$ of the world market in terms of timber and paper production. Less than $25 \%$ of the total annual allowable cut is used. Most of the timber cut in Russia is sold for export mainly in round form (about 40\%) and, as a result, our country produces 3-4 times fewer products of deep processing than in developed and some developing countries.

An urgent problem that needs to be addressed in the Russian forestry complex is an annual increase in the stock of low-quality wood pulp. Large reserves of such wood prevent reformation of deciduous plantations into more valuable conifers, and create such negative processes as fire hazard and forest pathology.

The volume of the considered residues in cutting area correlates with the season, tree species and other factors. Their average green volume is $50 \mathrm{t} / \mathrm{ha}$. With intensive farming, they account for up to $20 \%$ of the total mass or $50 \%$ of the stem mass. The largest part of the stem wood is made up by the crown, quantitatively this part correlates with the indicators of quality of the forest, stock and diameter of the forest, age and species

*Corresponding author: slava_shvecov@mail.ru 
composition of trees. In the cutting area, roots are mainly left - about $16-17 \%$ for spruce, $13 \%$ for aspen and $11-12 \%$ for pine. In addition, a large volume in the considered residues can be brushwood (up to $11 \%$ in relation to the exported wood). A small volume is made up of dead wood and fragments of trunks - 3.5-6\%, stumps - up to $3 \%$, tops - up to $1.5 \%$. A large amount of the considered waste is formed during the cutting of conifers (Table 1). [13]

Table 1. Amount of waste generated during logging production

\begin{tabular}{|c|c|c|c|c|}
\hline \multirow{3}{*}{$\begin{array}{l}\text { Name of logging } \\
\text { waste }\end{array}$} & \multirow{3}{*}{$\begin{array}{l}\text { Amount of waste } \\
\text { from removed } \\
\text { timber, \% }\end{array}$} & \multicolumn{3}{|c|}{$\begin{array}{l}\text { Waste amount per } 1000 \mathrm{~m}^{3} \text { of annual warehouse turnover } \\
\mathrm{m}^{3}\end{array}$} \\
\hline & & \multirow[b]{2}{*}{ Total } & \multicolumn{2}{|c|}{ Including } \\
\hline & & & At cutting area & $\begin{array}{c}\text { In lower } \\
\text { warehouse }\end{array}$ \\
\hline $\begin{array}{l}\text { Branches, twigs } \\
\text { and tops }\end{array}$ & 14.0 & 140 & 65 & 75 \\
\hline Roots & 11.0 & 110 & 110 & - \\
\hline Stumps & 3.0 & 30 & 30 & - \\
\hline Butting & 1.75 & 17 & - & 17 \\
\hline Slovens & 0.75 & 7 & - & 7 \\
\hline Sawdust & 1 & 10 & - & 10 \\
\hline $\begin{array}{l}\text { Bark and bast of } \\
\text { branches and tops }\end{array}$ & 3.0 & 30 & 14 & 16 \\
\hline $\begin{array}{l}\text { Bark of the middle } \\
\text { butt of the tree }\end{array}$ & 12 & 120 & - & 120 \\
\hline $\begin{array}{lr}\begin{array}{l}\text { Woody } \\
\text { (needles }\end{array} & \begin{array}{r}\text { greens } \\
\text { leaves) }\end{array} \\
\end{array}$ & $\begin{array}{c}36 \mathrm{~kg} \text { per } 1 \mathrm{~m}^{3} \text { of } \\
\text { exported wood }\end{array}$ & $36 \mathrm{t}$ & $18 \mathrm{t}$ & $18 \mathrm{t}$ \\
\hline $\begin{array}{l}\text { Needle-bearing } \\
\text { twigs, thin } \\
\text { branches }\end{array}$ & $\begin{array}{l}20 \mathrm{~kg} \text { per } 1 \mathrm{~m}^{3} \text { of } \\
\text { exported wood }\end{array}$ & $20 \mathrm{t}$ & $10 \mathrm{t}$ & $10 \mathrm{t}$ \\
\hline
\end{tabular}

The main consumers of wood raw materials are sawmills, pulp and paper, board and plywood enterprises. When processing wood, a large amount of waste is generated, when bucking logs - substandard (firewood) wood, twigs, branches, and bark, when trimming logs - long butts, when sawing wood raw materials - end cuts and cutting of boards, sawdust, waste from production of sleepers, waste container production.

Wood raw materials, which by their quality cannot be used as timber, are considered wood waste. This type of raw material also includes wood raw materials for technological processing and small-sized wood raw materials.

In order to increase the coefficient of integrated use of wood, technology and equipment were developed [4] (patents for invention No. 2673858 dated November 30, 2018 and No. 2698059 dated August 21, 2019) for processing of large branches and twigs into semifinished wood fiber, and woody greens of conifers into flour (Fig. 1). 

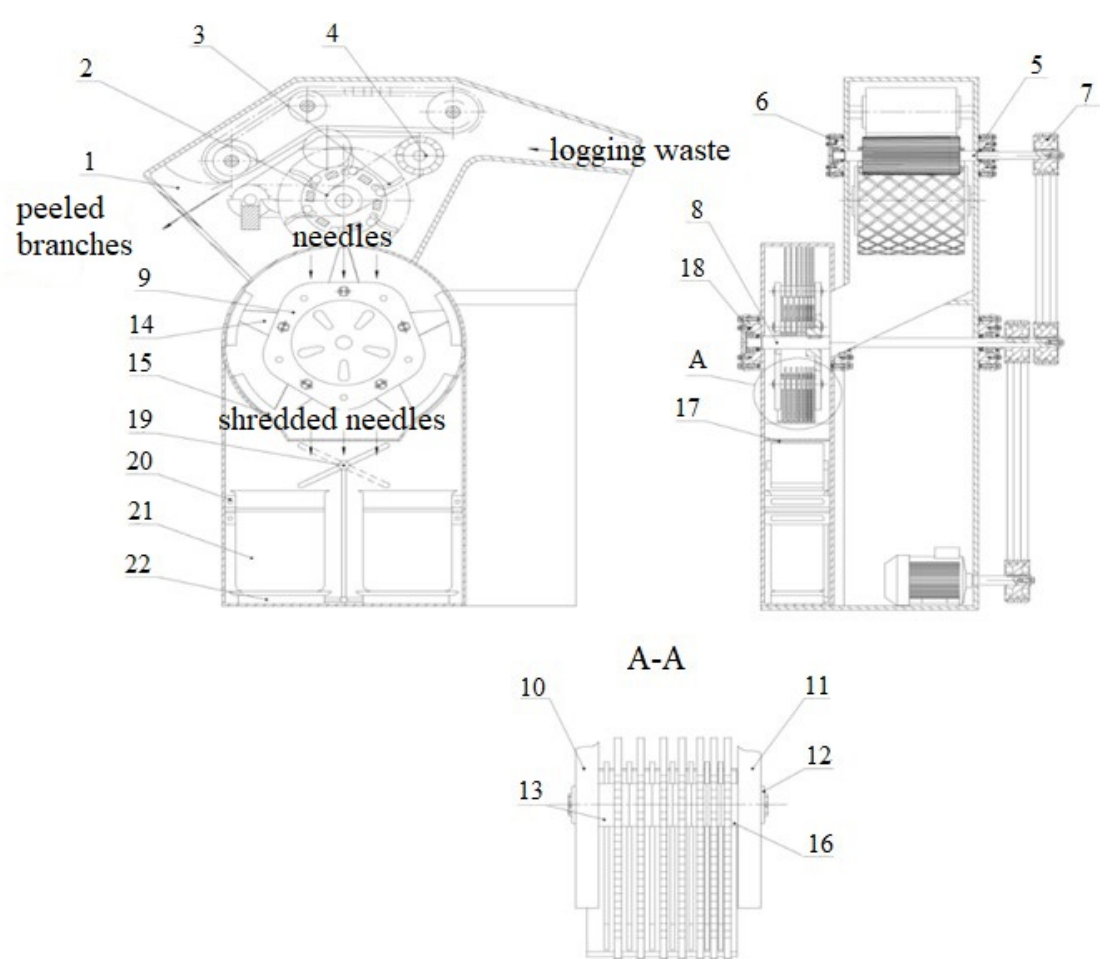

1 - case; 2 - drum; 3 - pins; 4 - feed roller; 5 - drum shaft of the woody greenery separator; 6 - bearing assemblies of the woody greenery separator; 7 - pulley of the woody greenery separator; 8 - rotor shaft of the grinder; 9 - grinder rotor; 10 - front rotor cover; 11 - rear rotor cover; 12 - end washers of the axles; 13 - knife hub; 14 - knife; 15 - counter knife; 16 - axis; 17 - replaceable sieve; 18 - bearing units of the grinder; 19 - rotary mechanism; 20 - vacuum packing machine; 21 - bag; 22 - scales.

Fig. 1. Diagram of a mobile plant for chopping woody greenery

Small branches and twigs without needles remain unused logging waste. Analysis of practical experience and works of modern researchers [5-7] showed that the most appropriate direction for using the remaining part of logging waste is production of wood flour, which has found its wide application in various industries.

Fig. 2 shows the proposed design of a mobile plant for shredding woody greenery.

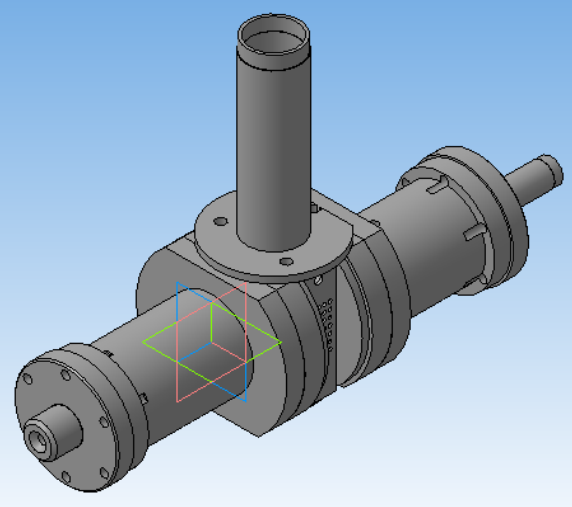

Fig. 2. 3D model of a grinding plant 
The principle of operation of the mobile installation is as follows: the raw material, presented in the form of branches and small-sized trees, is loaded butt-forward into the receiving part of the installation, after which it is captured by ribbed rollers, which feed it into the working area of the tree separation unit. Under the influence of pins, which are hinged on the drum shell, the needles are separated from the branches. With further movement, the peeled branches are brought out, and the needles are fed to the cutting unit under the influence of gravity. Greenery caught in the cutting zone is thrown by a rotating rotor, which creates an air flow, to the walls of the working chamber and is carried away by the knives in a circular motion.

The knives, moving in the product-air layer, hit the particles with their working surface and grind them. The crushed raw material, the size of which is smaller than the mesh size of the sieve, is removed from the cutting zone and, through a rotary mechanism, enter the bag, which stands on the scales.

After the separation of woody greens, a large number of coniferous legs remain, which can also be used to obtain wood flour.

To analyze processes and phenomena occurring in the working chamber of the machine, a 3d model of the working bodies has been developed, and it is shown in Fig. 2 and Fig. 3.

The milling process consists mainly of crushing and rubbing effects on the fiber that take place in the milling chamber. The drive shaft is connected to a belt drive through a belt drive pulley. As shown in Figure 3, the torque from the electric motor through the belt drive is transmitted to the drive shaft 1 , on which the crown with teeth 2 is installed. Due to engagement of the teeth of the crown of the driven shaft 3 , it rotates. Grinding is carried out in the gap between the teeth of the crowns.

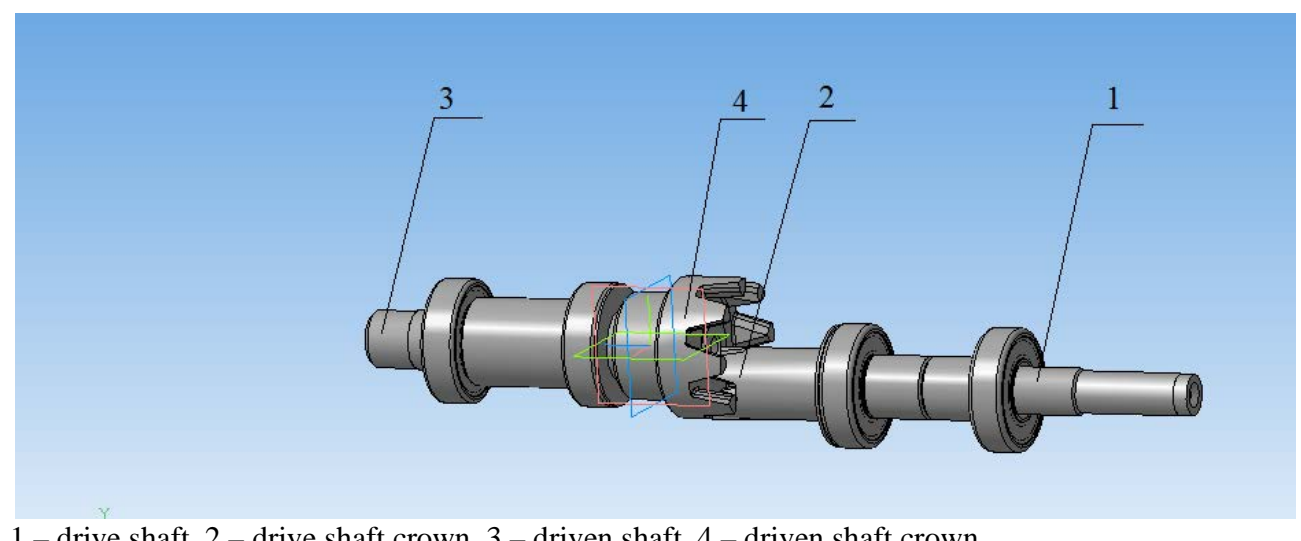

1 - drive shaft, 2 - drive shaft crown, 3 - driven shaft, 4 - driven shaft crown

Fig. 3. Grinding roller engagement

After analyzing the working processes of the $3 \mathrm{~d}$ model of the grinding unit, a laboratory prototype was made (Fig. 4). 


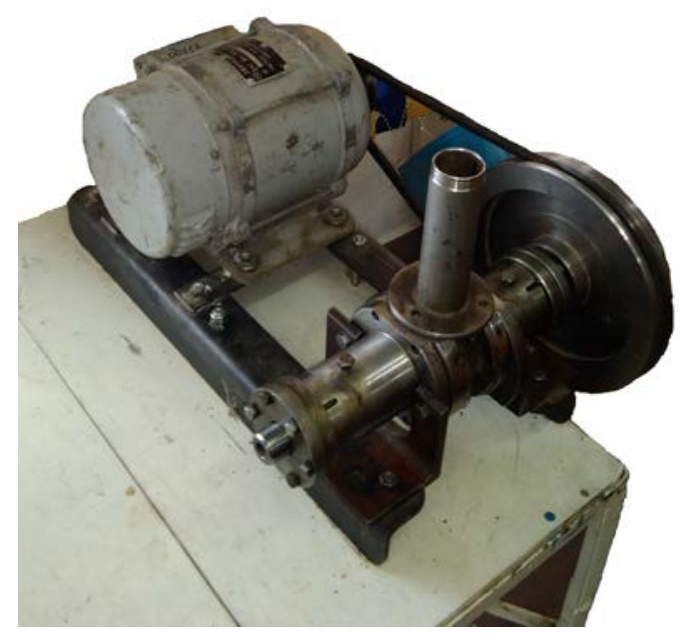

Fig. 4. Laboratory prototype of a device for obtaining wood flour from logging waste

Grinding of wood raw materials on a grinding installation enables you to get wood flour of 4 size fractions at the same time, as shown in Figure 5.

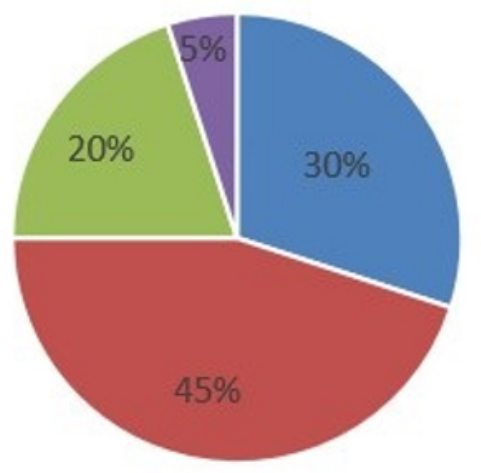

- $0,6-1,2 \mathrm{~mm}$

- 0,1-0,17 $\mathrm{mm}$

= $0,25-0,5 \mathrm{~mm}$

- 0,18-0,24 mm

Fig. 5. Distribution of the resulting wood flour by fractions

Thus, production of wood flour from branches and coniferous twigs without needles will reduce the amount of unused wood biomass left in the cutting area, which will have a positive impact on the environment and increase the coefficient of integrated wood utilization.

"The Project of an innovative design of a device for processing felling residues in the conditions of logging” is supported by the Regional Science Foundation. 


\section{References}

1. Mohirev A.P., Feldman N.V., Shevelev O. 2014. On the sustainability and exploitation of the resources of the Krasnoyarsk Territory Engineering Bulletin of the Don No. 4-1.

2. Nikishov V.D. Complex use of wood, Forest industry. 264 p.

3. Mohirev A.P., Bezrukikh U.A., Medvedev S.O. 2015. Processing of wood waste from timber industry enterprises as a factor of sustainable nature management. Engineering Bulletin of the Don. No. 2, Part 2. p. 81.

4. Patent No. 2673858 Russian Federation, IPC RU 95/00 (150302), C04B 26/26 (150302). Device for grinding wood chips in an aerodynamic environment: No. 2017135882: application 09.10.2017: publ. 30.11.2018. Zyryanov M.A., Syromyatnikov S.V., Khalmatov I., Baranov A. I.-7 p.: ill.

5. Zyryanov M.A., Dresvyankin I.A., Rubinskaya A.V. Experimental and theoretical substantiation of physico-chemical transformations of wood biomass in the production technology of wood-fiber boards. Engineering Bulletin of the Don. No. 4.

6. Zyryanov M.A., Medvedev S.O. Modeling of the process of obtaining wood-fiber semifinished products in order to expand the raw material base of timber enterprises. News of higher educational institutions. Forest journal. Arkhangelsk, pp. 176-183.

7. Zyryanov M.A., Syromyatnikov S.V. Development of measures to improve the efficiency of processing industrial waste of plant origin. Forest Engineering Journal. 2019. Vol. 9. No. 2 (34). pp. 164-171.

8. Krasnov N.P. and Lichman E.P. 2003. Rubilniki 1st ed., ster. - M.: ‘Academy’ Publ., $408 \mathrm{p}$.

9. Begunkov O.I., Vyvodtsev N.V., Guryev V.V. The use of low-quality wood and waste from the woodworking industry: a practical guide Khabar. GOS. Publishing House. UN-TA, 132 p. 